RESEARCH NOTES

\title{
The concept of personality in postmodern stories of the Turkish writer Bouquet Uzuner.
}

\section{El concepto de personalidad en las historias posmodernas del escritor turco Bouquet Uzuner.}

\author{
Alsu M. Nigmatullina \\ $\mathrm{PhD}$, Associate Professor of the Department of Altaic Studies and Sinology of the Institute of \\ International Relations, Kazan Federal University \\ ORCID ID: 0000-0001-9502-5371
}

\begin{abstract}
Alsu Ju. Giniyatullina
$\mathrm{PhD}$, Associate Professor of the Department of Foreign Languages in International Relations of the Institute of International Relations, Kazan Federal University

ORCID ID: 0000-0003-3080-0482

Glushkova Svetlana Yuryevna

$\mathrm{PhD}$, Associate Professor of the Department of Altaic Studies and Sinology of the Institute of International Relations, Kazan Federal University

ORCID ID: 0000-0002-5187-3632
\end{abstract}

Received 09-08-20 Revised 10-10-20

* Correspondence

Email: alsunigmatullina@mail.ru
Accepted 20-12-21 On line 03-01-21

\section{Citation:}

Alsu Mansurovna Nigmatullina, Alsu Junisovna Giniyatullina, Glushkova Svetlana Yuryevna. (2021). The concept of personality in postmodern stories of the Turkish writer Bouquet Uzuner. Propósitos y Representaciones, 9 (SPE2), http://dx.doi.org/10.20511/pyr2021.v9nSPE2.1051 


\begin{abstract}
The relevance of the problem is the need for an artistic understanding of the issues of social reorganization of the country, and to identify the relationship between the inner world of an individual and socio-political events that influenced the artistic specificity of modernist literature. The purpose of this article is to consider the philosophical categories of alienation and loneliness and their embodiment in the literary and artistic field. The main results of the study are in understanding the formation of a new mentality, in the formation of a new personality, designed to be perceived as not only a literary phenomenon, but also as socio-political and cultural-historical one.
\end{abstract}

Keywords: modern literature, literary trends, loneliness, alienation, social contradictions

\title{
Resumen
}

La relevancia del problema radica en la necesidad de una comprensión artística de los problemas de la reorganización social del país, y de identificar la relación entre el mundo interior de un individuo y los hechos sociopolíticos que influyeron en la especificidad artística de la literatura modernista. El propósito de este artículo es considerar las categorías filosóficas de alienación y soledad y su encarnación en el campo literario y artístico. Los principales resultados del estudio están en entender la formación de una nueva mentalidad, en la formación de una nueva personalidad, diseñada para ser percibida no solo como un fenómeno literario, sino también sociopolítico y cultural-histórico.

Palabras clave: literatura moderna, tendencias literarias, soledad, alienación, contradicciones sociales.

\section{Introduction}

Postmodernism, which created a fundamentally different system of values, inherited from the previous stages of Turkish literature (subjective psychological prose, literature of "alienation") an idea related to the spiritual search. This idea remains decisive, and implemented within various frameworks. Another feature that combines Turkish postmodernism and the literature of "alienation" (also the literature of the "crisis") is the theme of the worldview crisis, the spiritual search. But, unlike the literature of "alienation" (Zaitsev, Ulchenko, 2008, p. 218), postmodernism does not emphasize the opposition "man-society", but on the contrary, it creates a new concept of personality for Turkish literature, in which there is no place for dissociation between people and the world. A person recognizes oneself as equal to the world, a kind of microcosm, which incorporates the whole ambiguous and absurd world. Such experiences are not perceived as something out of the ordinary; on the contrary, they are organically intertwined with the everyday life of the characters. Perhaps it is precisely this feature of postmodernism that allows us to talk about the optimistic tonality of the writer Bouquet Uzuner.

Another argument in favor of this point of view is the fact that the narratives of Bouquet Uzuner, where the main theme is reinterpretation, the search for the life purpose, are optimistic. Postmodernism - and this is fundamentally different from modernist trends - does not impose its style of thinking on anyone. In addition to the above, it does not find it necessary to convince of a successful result. The examples of this idea are two "attitudinal" stories of Bouquet Uzuner "Fantasies that did not submit to either their country or reality" and "A gypsy who swallowed the sun". It is noteworthy that the title of the second story gave the title to the entire collection, which emphasizes its semantic significance.

Bouquet Uzuner was born in 1955 in the capital of the Turkish Republic - the city of Ankara. Having received a diploma from the Faculty of Biology of the University of Hajettepe, 
she continued her research in microbiological ecology and sociology at the University of Norway at Bergen and at the University of Michigan the USA, and worked as a teacher at the University of Tampere (Finland) in the field of environmental protection.

The prose of Bouquet Uzuner has been published since 1977 in the periodicals «Varlyk», «Goesteri», «Gergedan», «Olushum», «Donemech». Bouquet Uzuner is a laureate of literary awards such as the Yunus Nadi Prize for the novel "The Sound of Fish Traces" and the prize of the Faculty of Communications of Istanbul University for the novel "Sand Island - Blue Tune".

\section{Methods}

The analysis of the Bouquet Uzuner's works must be studied in the unity of form and content, which allows revealing the author's world views. The theme of creativity and the theme of human relationships united by a common theme - the theme of dreams and creation is the most significant in the study of Bouquet Uzuner creativity. The tradition to define creativity not only as an act of transformation, but to define an element of creativity as a symbol of attraction (often men to women) is interesting and peculiar. This trend can be seen in the story ("The hidden Letters of Anais"), where the central character - a young man who recently divorced after five years of marriage, moves to a new apartment. At the beginning the goals of the central character are modest and uncertain - to start a new life, to get rid of the bitterness of the past and the collapse of hopes, then after finding in the cache the letters of his former tenant to her beloved the central character's aspirations change dramatically.

They are very emotional, and gradually the imagination takes up over reality. A significant detail of this victory is the change of name. The real, rather prosaic name of the mistress of letters Aichakhanym - is replaced by an outlandish nickname - Anais. Gradually, in the besotted imagination of the character, the whole image of Anais - a smart, subtle, very emotional and very lonely woman - is completed. Despite the fact that the very fact of the heroine's frank letters to a man who is not at all interested in her, sometimes leads to the idea of some vulgarity of the main character, the main character falls into the charms.

The creativity in this story concerns not only the heroine (letters revealing her soul), but also the hero - it is he who, on the basis of her letters, recreates the image of the heroine by the power of his imagination.

The theme of creativity and childhood, as a period when people have creative power, is able to create and transform reality, combines the following story - "A gypsy who ate the sun". The story can be called philosophical, so capaciously it combines the whole life of the character from rebellious childhood to a "normal" adult life. The sun is a symbol of the unattainable, a symbol of a dream, what the hero asked for as a gift in childhood. The conflict between aspirations and reality begins with the mother's answer: ("Learn to abandon the unattainable, you have already grown!") (Uzuner, 2002, p. 97).

His dream develops a character, thanks to which he strives forward. Attention should be paid to the fact that in a "normal" adult life, abandoning a dream ultimately leads to a gradual abandonment of an interesting, real life: verses hide in a drawer of a table, the trickle where the character played as a child dries up. "I could not fall in love with reflections and conversations within strictly defined boundaries, sitting at hated desks") (Uzuner, 2002, p. 81).

The story has many philosophical notes, layers of meanings, which again refer us to the unification of philosophy and literature (in the period of postmodernism). This is the motive of worshiping the sun in pagan times, and the motive of the desire to have the sun (although the rest will be in the dark), and the image put out in the name is a gypsy woman who ate the sun, which appears in the character's dream with the words "You love a woman, her name - The sun". The conflict that took place in reality is repeated again in a dream - the antagonist - the mother, saying, "Learn to abandon the unattainable." In the image of a gypsy, fate itself predicts. 
We see the further development of the theme of creativity in the story "Violet and the rest", where the gradation is manifested in the fact that creativity acts as a creative force not only of art (letters, paintings as before), but of life itself. The ability to manage one's destiny is part of character of strong women who are being narrated. Son, grandson, lover - a link between them.

The theme of love and relationships between a man and a woman is found in almost every story of Bouquet Uzuner. Analysis of stories where this topic is one of the main one, we made an assumption about the pessimistic mood of Bouquet Uzuner in relation to the possibility of a trusting, long relationship, where feelings would not come to naught.

We led to this conclusion by the fact that in the series of stories we are studying there are only two examples of happy marriages: in the story "Violet and the rest" and "Woman in a man", but after analyzing, we considered them as exceptions, since in the first case the main emphasis is on the strength of spirit of women (consequently, the author could emphasize the main idea with a happy marriage), and in the second case, the author introduces a parallel of two plots - fantastic (where the woman was inside the man) and real, where the character did not find happiness in marriage.

It is interesting that the characters of Bouquet Uzuner state both their feelings and the reason of their problems very accurately, and do this in a concise form, in one or two drafts. So here - the character sees the reason for his source of friction in the routine of life.

\section{Results and Discussion}

As a modern writer, Bouquet Uzuner also responds in a few sketches to changes in the position of women in the Turkish society. In this regard, both the changing model of the position of women in society and the sad changes in the number of strong families are very demonstrative.

Along with the plot, one of the most important components of the work is a chronotope, which is also characteristic of the Bouquet Uzuner narrative. The association under the term "chronotope" of the place and time of the work belongs to the researcher M. M. Bakhtin.

A chronotope is a formally meaningful category of literature expressing the continuity of space and time in a work of art. "In the literary and artistic chronotope, there is a fusion of space and time signs in a meaningful and concise whole. Time is condensing, thickening, getting artistically visible; space is intensified, drawn into the movement of time, plot, and history. The signs of time are revealed in space, and space is conceptualized and measured by time. Artistic chronotope is characterized by this intersection of rows and the merging of signs" (Bakhtin, 1975, p. 234).

The first thing in the Bouquet Uzuner stories that attracts the readers is fragmentation (the structure of the composition, when the story is assembled in several parts, like a mosaic) and a kind of expansion, both of time and space.

The term "fragmentary composition" itself has an analogue that is widely used by literary scholars - "editing", which is understood as a method of constructing a literary work in which the discontinuity of the image and its "breakdown" into fragments prevail. Cutting composition is one of the most beloved ones by Bouquet Uzuner. The essence of the free (cutting) form of event composition is associated with violations of cause-effect and spatial relationships between events. The connection between episodes is more often associative-emotional than logical-semantic in nature. The cutting composition is characteristic of 20th century literature. (https://studbooks.net/17041/literatura/kompozitsiya_syuzhet) The story "Violet and others": entirely consists of separate plot parts - the characters tell their stories. At first glance everything that seems to be a chaotic pile up gradually turns out to be a harmonious history of one family. An interesting choice of framing epigraphs creates a circular composition. 
This approach allows to figuratively capturing not observed relationships of phenomena, to deeply comprehend the world in its diversity and richness, indecipherability and unity. This approach corresponds to a vision of the world that is diverse and epic in breadth.

"Epic breadth", in other words, "the ability to expand space and narrative time" is characteristic of Bouquet Uzuner. Bouquet Uzuner creates most of her works in the form of rather extensional stories, reminding of novels. Space and time are changing rapidly, as if it was a travel novel. Each page of Bouquet Uzuner's works has so much diversity.

Having traveled to a large number of countries, Bouquet Uzuner considers travel a very serious matter, in her works she finds ways to convey the diversity of the world.

The first feature that should be mentioned is "the incompleteness of the artistic time" (Chernets, 2004, p.191). Closed (in other words, completed) time means the presence of an absolute beginning and an absolute end to the plot of a work; The absence of the open final, the outcome of the conflict (returning to the fold; achieving sustainable livelihoods; death; wedding).

The incompleteness of artistic time is a sign of 20th-century literature in relation to earlier stages. The boundaries between the clearly defined framework of literature and life seem to blur.

Another feature of the artistic time of Bouquet Uzuner narratives is - density, that is, a large number of events, covering a large time period.

Not only time, but space also creates a sense of "expansion" in the narratives of Bouquet Uzuner. This is achieved by the inclusion in the narrative of many places, those that become the platform for what is happening, just like those that are only mentioned - also create a feeling of a peculiar cosmopolitanism.

The desire for details is another significant feature of the writer we are studying. In a stylistic sense, this is a depiction of the situation with several important details, which are often so important that they reach the status of symbols. The whole situation is outlined with several details, and their repetition creates a peculiar atmosphere of the story. Hence the effect of emotionality arises; the narrative is painted in personal tones. To continue the study of the effect of stories, we consider the language features.

Linguistic features also create trust, as if the author seeks to create a "very personal" dialogue between themselves and the reader. This is facilitated by such means as:

- Interactive narrative form

- Reflection questions - they are often addressed to the reader - the imaginary reader does not lose sight of - they argue with reader, they consult with reader.

The lightness of the language is uncomplicated syntax, which also works to build trust. At the same time, there are borrowings from other languages.

The fiction text reflects not only the richness of a language and style, but also features the development of the standard language and changes in its lexical composition. It is also expedient not only to read the literature, but also the ability to analyze any literary work in the language this work is written. Methodology for teaching students the analysis of Turkish fiction texts (Rakhimova, Nigmatullina, 2019, p.13-16). The analysis of various aspects of Bouquet Uzuner creativity allows making an approximate picture of the writer's world. First of all, the author's commitment to existential topics (creativity, love) deserves attention, to which the reader is invited to reflect. This is facilitated by the dialogue form of the narrative, the involvement of the reader in the work. In a stylistic sense, the creativity of Bouquet Uzuner is characterized by eclecticism, fragmentation, and dynamic presentation of the narrative. Poetics is thus a rearranging of the hierarchy of what signification within the speech event is dominant at any moment. Discourse operates on many levels simultaneously, but speech acts release differing meanings in their poetic function than they do in their referential or emotive functions (Larkin Barnard 2013, pp 327-343). 


\section{Summary}

Postmodernism of Bouquet Uzuner with sincerity, loneliness (more like retreat) is both a reflection of social changes taking place in the society, and a meditative rethinking of the world and its place in the world, since "in the specifics of art, starting with Aristotle's "Poetic Art", it has always been emphasized how figurative reproduction of reality ("imitation"), as well as the generalization concluded in artistic images, achieved by creative implementation, recreation of reality". "The peculiarity of postmodernism is that it summarizes the accumulations of all cultural eras, at the same time exposing their values to decanonization. Postmodernism is a "synthesis of a return to the past and movement forward"(Skoropanova, 2001, p. 283). Turkish postmodernism, adopting the American experience and Western European art, was not limited, ultimately, to thoughtless copying; moreover, it developed along its own path; and since it was not a superficial direction, it had previous trends.

\section{Conclusions}

In recent decades the Turkish critics and writers notice that traditional trends have been losing their clarity and distinctiveness. It has led to a new tendency embodying the principles of postmodern literature. This perception of reality was facilitated by the active development of computer technologies, games, virtual worlds of the Internet, the power of the media, which increasingly influence social psychology.

\section{Acknowledgements}

The work is performed according to the Russian Government Program of Competitive Growth of Kazan Federal University.

\section{References}

Bahtin, M.M. (1975). Voprosy literatury i jestetiki. — M.: Hudozh. lit. - 234 p.

Buket Uzuner. (2002). Güneş yiyen çingene - İstanbul.

https://studbooks.net/17041/literatura/kompozitsiya_syuzhet

Muhametzyanov, R.R., \& Usmanova, I.R. (2018). The Problem of Destiny in Ancient Chinese Philosophy. Revista Publicando, 5(16(1)), 617-622.

Rakhimova, A.R., \& Nigmatullina, A.M. (2019). Methodology for teaching students the analysis of Turkish fiction texts. http://ijhe.sciedupress.com. International Journal of Higher Education, 8(7), 13-16. Published by Sciedu Press 13 ISSN 1927-6044 E-ISSN 19276052.

Skoropanova, I.S. (2001). Russkaja postmodernistskaja literatura: Ucheb. posobie dlja studentov filol. fak. - M.: Flinta: Nauka,.-283 p.

The Politics and Poetics of Infrastructure Annual Review of Anthropology, Volume 42, 2013, New York, NY 10027-6598; email: bl190@ columbia.edu334-335, pp 327-343

Turcija na rubezhe XX - XXI vekov /Otv.red. I.V.Zajcev, N.Ju.Ul'chenko; IV RAN.-M.: Tipografija MGU, 2008. - $218 \mathrm{p}$.

Vvedenie v literaturovedenie: ucheb. posobie dlja studentov vuzov, obuchajushhihsja po napravleniju i special'nosti "Filologija" / L. V. Chernec [i dr.]; Pod red. L. V. Chernec.-M.: Vyssh. shk., 2004.-191 p. 